\title{
The Dark Side of GTA: Chinatown Wars
}

\author{
Kevin George
}

Department of English, K.E College, Mannanam, Kerala, India

\begin{abstract}
Released way back in 2009, Grand Theft Auto: Chinatown Wars is an action-adventure videogame, developed for a console meant for teenagers. However, the videogame drew flak for its inclusion of certain controversial mini-games and missions involving drugs like cocaine and heroin. This short essay/review will focus on the corruptive influence of something as trivial as a videogame and how it works insidiously as a lure to a world of crime, which young minds find irresistible.
\end{abstract}

Keywords-Addiction,Arson, Delusions of power,Drug-dealing, GTA: Chinatown Wars.

\section{INTRODUCTION}

I was having a hard time coming to terms with the quarantine in India (and the world over). Usually, I would find solace in reading philosophy and literature or I would binge on my favourite films or series. But, the headlines and podcasts made sure that my usual sangfroid was kept at bay. My penchant for etymology compels me to mention the origins of the word 'sangfroid'. It comes from French sang-froid, literally, cold blood (or cold-blooded). We can't afford to be cold-blooded right now. So, I think it's not a bad thing, after all. I needed a distraction. I picked up my old gaming console (a Nintendo DS) and decided to play Grand Theft Auto: Chinatown Wars, a 2009 action-adventure video game developed by the mavens of the lucrative gaming business, Rockstar Leeds. I spent an hour or two in Liberty City(Chinatown in particular) indulging in the vicarious thrills offered by the game including carjacking and arson, which are hackneyed themes in almost all the other GTA games. Then, something dawned upon me which almost made me disconcerted. I remembered warning my students to stay aloof from drug peddlers and gangs with a predilection for anti-social activities. They vitiate young minds, don't they? It seemed as though I were contradicting my words by playing a videogame that promoted wanton cruelty, at times, forcing me to draw parallels with Anders Breivik, the perpetrator of the 2011 Oslo attacks which left close to 60 people dead. But, this is a simulacrum... I was trying in vain to justify the schadenfreude.

The game became a hit and in 2014, it was released on other platforms including iOS and android. It will come as no surprise that despite the $18+$ warning, the users who have downloaded the game the most are teenagers. I was reminded of William Golding's prescient notion of adolescent innocence as portrayed in his novel The Lord of the Flies. 'Influence' plays a big role and so does the milieu. The pandemic (COVID19) which is wreaking havoc on our planet has made their lives insular and more susceptible to 'influence' (at least for now) and things aren't much different (from the novel). The teenagers who spent hours playing games like GTA: Chinatown Wars, (I will focus on this particular game because it is more addictive and offers an omniscient point of view, unlike its predecessors) tend to imbibe a false sense of superiority. We know what happened on that island (The Lord of the Flies) when a group of ingenuous kids were left to fend for themselves. I wonder if the players (both teenagers and adults) feel like gods when they vicariously participate (or orchestrate) in heists, vandalism and worst of them all, drug-peddling. Yes, that's what struck me as odd. To make matters worse, the drug peddling missions can't be skipped. It's not even a matter of 'either or'. Unless you buy or sell cocaine, (and other drugs) the triad bosses won't show an interest in you or your criminal record. I wasn't the only person who had to face a similar predicament. "Is it possible to trade acid or ecstasy for coke?" asked my cousin who is a teenager. Interestingly, the game won numerous accolades including the coveted VGX award for the best handheld game. As in Golding's novel, the kids who spent hours playing the game have absolute control over a world where they can choose to punish or kill with impunity. They tend to internalize violence (as they are young) and might even bring up 'drug-dealing' patois over dinner to the chagrin of people around them.

The plot is too convoluted for a console game. The game's story follows the adventures of Huang Lee, the spoiled son of a Triad boss (who was an unscrupulous gangster). Following the murder of his father and the theft of his 
family sword (a katana), Huang leaves for Liberty City where he hopes to meet his uncle 'Kenny' and establish connections with several high profile drug lords of Asian descent. The developers of the GTA games, it seems, have a penchant for people of Asian and Afro-American descent. As I mentioned earlier, the game is played from a top-down perspective, with a rotatable aerial camera that allows the players to dynamically change angles during action sequences (omniscient view). This gives them full control over a simulated world. To make matters worse, the game is very addictive and the players (especially teenagers) might develop delusions of power over a period of time. Nintendo DS was originally meant for kids. The inclusion of a drug-dealing mini-game, as I mentioned earlier, invited vitriolic comments from critics all over the world and had also figured in some reviews. The infamous drug-dealing game (within the game) allows one to peddle six different drugs around the city including heroin, weed, ecstasy, cocaine, downers and acid. The players are expected to make profit which depends, to an extent, on the fluctuating market conditions. Imagine our kids mastering the subtle art of drug-peddling at an age when their inchoate minds ought to invest more time in reading and developing new skills. One of the developers had the audacity to justify the stand of the GTA franchise without mincing words.

"Nintendo wanted us to make GTA, and we wanted to make a game on their platform. They didn't want us to make a GTA for kids, and we weren't interested in making a game we wouldn't normally make"

The game also has a huge focus on weaponry as its predecessors - Desert eagles, machine guns, mini guns, flame-throwers, Molotov cocktails are all available, and the gamers could go on a killing spree like Breivik or the perpetrators of the recent Christchurch attacks. Players can also make use of the 'lock-on' system to target and annihilate enemies (or innocent bystanders). You can also master the art of crafting Molotov cocktails, the standard weaponry of guerrilla warfare and violent rioters. Molotovs,as we all know, became popular during the Second World War and was used by all sides. They were mass-produced by the Finnish military and had already been used by the guerrillas in the Spanish Civil War. If the French literary critic and semiotician Roland Barthes had dedicated a piece to this weapon, (in his Mythologies) he would have certainly decoded the myth behind its proletarian/rebel origins for us. In spite of his erudition in Marxism and Existentialism, Barthes didn't bother to interpret this Russian sign (The name 'Molotov' is derived from a Russian communist). There are other mini-games that work like crash courses on hot-wiring cars, bulldozing exotic cars into the sea, kidnapping members of the rival gangs and setting gas stations ablaze. Including all this could have been extenuated if they had launched GTA: Chinatown wars on a mature platform, like the Play Station or the Xbox. But, instead, they had to pick a console like the Nintendo DS which was originally meantfor teenagers.

Unlike the other GTA games, the player can disable as many police cars as possible to evade the police instead of seeking hideouts desperately. The more stars the players have, the more police they have to take out for each level. The developers have also introduced an in-game website where the player can order the weapons of their choice (or indulge in drug-dealing). GTA: Chinatown wars also takes vandalism and arson to the next level. CCTV cameras could be disabled or sabotaged by throwing Molotov cocktail bottles or a grenade. This also decreases the chances of being caught while you are negotiating the drug-deals.

"GTA: Chinatown Wars continues to be the highest rated Nintendo DS game ever, with an average review score of $93 \%$. IGN UK gave it a rating of 9.2, calling it 'a masterpiece of handheld gaming', while IGN US gave the game 9.5 out of 10. In the United States, it sold just under 90,000 units during its first two weeks on the American market."

A review that Irecently came across on IGN (a website for videogame reviews) specifically draws attention to the advantages that this game has over its predecessor (GTA IV), including, the availability of chainsaws and flamethrowers. I couldn't bring myself to think about the impact of a video game characterised only by wanton destruction, violence and everything vile. Kids will spend hours playing this game on their consoles. The psychological effect games like GTA: Chinatown Wars have on our children is irreparable and before we know, they will be sucked into a vortex of evil which will eventually leave their minds incorrigibly corrupt. The idea behind this review or vitriolic, if I may, is to draw your attention to a matter of utmost gravity, that is being consciously undermined by the giants of the gaming industry.

\section{REFERENCES}

[1] Dan Houser, David Bland. GTA Chinatown Wars Wiki Guide-GTAWiki. Retrieved from GTA Fandom,

https://gta.fandom.com/wiki/Grand_Theft_Auto:_Chin atown_Wars 